\title{
Natural killer cell activity in the peripheral blood of patients with Cushing's syndrome
}

\author{
Rosa Gabriella Masera, Antonio Staurenghi, Maria Luisa Sartori and Alberto Angeli \\ Clinica Medica Generale, Dipartimento di Scienze Cliniche e Biologiche, Università degli Studi di Torino, Regione Gonzole 10, 10043 Orbassano \\ (Torino), Italy \\ (Correspondence should be addressed to R G Masera, Dipartimento di Scienze Cliniche e Biologiche, Clinica Medica Generale, Azienda Ospedaliera San \\ Luigi, Regione Gonzole 10, 10043 Orbassano (Torino), Italy)
}

\begin{abstract}
Background: Natural killer (NK) cells are $\mathrm{CD} 3^{-} \mathrm{CD} 16^{+} \mathrm{CD} 56^{+}$bone-marrow-derived lymphocytes mediating first-line defence by direct cytotoxicity against various types of target cells without prior immunization. NK cell activity is positively regulated by immune interferon (IFN- $\gamma$ ); among hormones, glucocorticoids are potent in vitro and in vivo inhibitors, whereas ACTH and $\beta$-endorphin in many experimental circumstances enhance NK cytotoxicity.

Design: We measured NK cytotoxicity of peripheral blood mononuclear cells (PBMC) obtained at $0800 \mathrm{~h}$ and $2000 \mathrm{~h}$ from 26 patients with Cushing's syndrome (12 pituitary-dependent, 12 adrenaldependent and two dependent on ectopic ACTH secretion). In vitro responsiveness to IFN- $\gamma$ or cortisol was also tested.

Methods: NK activity was measured in a 4-h direct cytotoxicity assay using K562 cells as targets. Plasma ACTH, serum and urinary free cortisol were concomitantly measured with commercially available kits.

Results: Spontaneous activity and responsiveness to IFN- $\gamma$ or cortisol were significantly greater in 15 age- and sex-matched controls than in Cushing's patients at $0800 \mathrm{~h}$. In pituitary-dependent Cushing's patients, plasma ACTH correlated positively with mean levels of spontaneous NK activity $(r=0.64, P<0.05)$ and negatively with cortisol-dependent percentage inhibition $(r=-0.69, P<0.02)$. In adrenal-dependent Cushing's patients, a negative correlation was observed between levels of spontaneous NK activity and urinary free cortisol $(r=-0.67, P<0.02)$.

Conclusions: Our data indicate that excess endogenous glucocorticoids affect spontaneous NK cell activity and responsiveness to exogenous IFN- $\gamma$ or cortisol. The differential patterns observed between pituitary-dependent and adrenal-dependent groups are compatible with a positive immunomodulatory role of pituitary pro-opiomelanocortin-derived peptides that effectively counterbalance, at least partially, glucocorticoid immunosuppression.
\end{abstract}

European Journal of Endocrinology 140 299-306

\section{Introduction}

Natural killer (NK) cells are a subset of bone-marrowderived lymphocytes with large granular morphology and phenotypically characterized as coexpressing the cell surface antigens CD16 and CD56, and lacking the CD3/T cell receptor complex $(1,2)$. These cells mediate first-line defence by direct cytotoxicity, without prior immunization, against various types of target cells that lack or down-regulate major histocompatibility complex class I molecules and thereby escape detection by cytotoxic T lymphocytes (3).

Most components of the biology of NK cells are regulated by interleukins (IL) such as IL-1, IL-2, IL-10 and, notably, IL-12, which has the ability to induce the synthesis of immune interferon (IFN- $\gamma$ ) by NK cells themselves. IFN- $\gamma$ is, indeed, a key molecule for phenotypic differentiation and functional activation of these cells $(4,5)$. Hormones are also known to be important regulators of natural cytotoxicity. Glucocorticoids are potent in vitro and in vivo inhibitors of $\mathrm{NK}$ cell activity (6-9), through the mediation of classic glucocorticoid receptors and the reduction of cytosolic calcium availability (10). In contrast to glucocorticoids, two pro-opiomelanocortin (POMC)-derived peptides, adrenocorticotrophic hormone (ACTH) and $\beta$-endorphin, have been found to be positively influential upon NK cytotoxicity $(9,11,12)$. We demonstrated that both ACTH and $\beta$-endorphin enhance the cytokine-induced NK activity and reduce the cortisol inhibitory effect $(9,12)$.

An interesting feature of NK cell activity is its circadian organization. Both the spontaneous cytotoxicity and the in vitro susceptibility to cortisol and IFN- $\gamma$ oscillate throughout the 24 -h cycle $(13,14)$. Previous work by our group demonstrated that 
spontaneous NK cell activity and IFN- $\gamma$-dependent boosting of cytotoxicity peak early in the morning, reaching lower levels in late afternoon. In contrast, glucocorticoid-dependent inhibition was observed at its maximum in late evening or night. The circadian variations of NK cytotoxicity are conceivably connected with rhythmic changes in soluble regulatory factors, including hypothalamo-pituitary-adrenal (HPA) hormones among others $(15,16)$.

The clinical relevance of increased susceptibility to bacterial and mycotic infections in Cushing's syndrome is obvious $(17,18)$, yet specific immune functions in such patients have been poorly investigated and to the best of our knowledge no systematic study of NK cell function and responsiveness to physiological modifiers has been reported.

We have focused on NK activity of peripheral blood mononuclear cells (PBMC) in patients with Cushing's syndrome, either dependent on excess ACTH (Cushing's disease or ectopic secretion) or having an autonomous adrenocortical hypersecretion. Two opposite circadian stages were considered for both spontaneous cytotoxicity and in vitro responsiveness to positive (IFN- $\gamma$ ) or negative (cortisol) physiological modifiers.

\section{Subjects and methods}

Twenty-six patients with Cushing's syndrome, 12 pituitary-dependent, 12 adrenal-dependent and two ectopic ACTH-syndromes ( 3 men and 21 women, age range 22-60 years) were enrolled in the study (Table 1). All patients had active disease and had not undergone previous treatment. The diagnosis of Cushing's syndrome was based on standard criteria. As controls, 15 healthy normal volunteers ( 3 men and 12 women, age range 2458 years) were recruited from the laboratory staff. Neither patients nor controls were receiving medication or displayed any clinical sign of infection.

All controls and patients participated in the study after giving their informed consent. Procedures followed were in accordance with the ethical methods of the institutional responsible committee on human experimentation. Consumption of ethanol and smoking were not allowed in the last $72 \mathrm{~h}$ before blood was drawn. Between $0800 \mathrm{~h}$ and $2000 \mathrm{~h}$, participants were kept in a quiet environment and allowed to eat, sleep and nap ad libitum.

Heparinized blood samples were drawn from patients and controls at two opposing times of the day $(0800 \mathrm{~h}$ and $2000 \mathrm{~h}$ ) and PBMC were immediately separated. Before the NK cytotoxicity assay, effector cells were incubated for $20 \mathrm{~h}$ in the presence or absence of modifiers: recombinant IFN- $\gamma(\mathrm{rIFN}-\gamma)$ or cortisol. In addition, blood samples were concomitantly collected from patients for plasma ACTH and serum measurement of cortisol.

\section{Preparation of PBMC and NK activity assay}

PBMC were isolated from heparinized peripheral blood by Ficoll-Paque (Cederlane, Ontario, Canada)

Table 1 Clinical and hormonal characteristics of patients with Cushing's syndrome.

\begin{tabular}{|c|c|c|c|c|c|c|c|c|}
\hline \multirow{2}{*}{$\begin{array}{l}\text { Patient } \\
\text { no. }\end{array}$} & \multirow[b]{2}{*}{ Sex } & \multirow[b]{2}{*}{ Age $(y r)$} & \multirow{2}{*}{$\begin{array}{c}\text { Duration (yr)/ } \\
\text { histology }\end{array}$} & \multicolumn{2}{|c|}{ ACTH (pg/ml) } & \multicolumn{2}{|c|}{ Cortisol ( $\mu \mathrm{g} / \mathrm{dl})$} & \multirow{2}{*}{$\begin{array}{c}\text { Urinary free } \\
\text { cortisol }(\mu \mathrm{g} / 24 \mathrm{~h})\end{array}$} \\
\hline & & & & $0800 \mathrm{~h}$ & $2000 \mathrm{~h}$ & $0800 \mathrm{~h}$ & $2000 \mathrm{~h}$ & \\
\hline 1 & $\mathrm{~F}$ & 56 & $2 / \mathrm{pa}$ & 14 & 14 & 16 & 25 & 177 \\
\hline 2 & $\mathrm{~F}$ & 47 & $3 / \mathrm{pa}$ & 17 & 17 & 18 & 13 & 111 \\
\hline 3 & $\mathrm{~F}$ & 58 & $3 / \mathrm{pa}$ & 68 & 66 & 17 & 16 & 323 \\
\hline 4 & $\mathrm{~F}$ & 25 & $4 / \mathrm{pa}$ & 18 & 21 & 20 & 17 & 700 \\
\hline 5 & $\mathrm{~F}$ & 48 & $1 / \mathrm{pa}$ & 34 & 38 & 19 & 16 & 288 \\
\hline 6 & $\mathrm{~F}$ & 60 & $2 / \mathrm{pa}$ & 58 & 66 & 18 & 26 & 152 \\
\hline 7 & $\mathrm{~F}$ & 55 & $5 / \mathrm{pa}$ & 58 & 41 & 11 & 4 & 282 \\
\hline 8 & $\mathrm{~F}$ & 43 & $2 / \mathrm{pa}$ & 18 & 15 & 13 & 9 & 153 \\
\hline 9 & $\mathrm{~F}$ & 24 & $1 / \mathrm{pa}$ & 98 & 79 & 17 & 13 & 146 \\
\hline 10 & $\mathrm{~F}$ & 60 & $4 / \mathrm{pa}$ & 82 & 88 & 16 & 20 & 300 \\
\hline 11 & $M$ & 35 & $3 / \mathrm{pa}$ & 38 & 35 & 18 & 14 & 184 \\
\hline 12 & $M$ & 19 & $1 / \mathrm{pa}$ & 42 & 60 & 18 & 26 & 140 \\
\hline 13 & $M$ & 44 & $2 /$ aa & $<5$ & $<5$ & 29 & 25 & 238 \\
\hline 14 & $\mathrm{~F}$ & 46 & $1 /$ aa & $<5$ & $<5$ & 45 & 41 & 730 \\
\hline 15 & $M$ & 50 & $2 /$ aa & $<5$ & $<5$ & 55 & 33 & 1800 \\
\hline 16 & $\mathrm{~F}$ & 28 & $1 /$ aa & $<5$ & $<5$ & 23 & 21 & 357 \\
\hline 17 & $\mathrm{~F}$ & 45 & $1 / \mathrm{aa}$ & $<5$ & $<5$ & 19 & 18 & 270 \\
\hline 18 & $\mathrm{~F}$ & 22 & $2 /$ aa & $<5$ & $<5$ & 27 & 30 & 465 \\
\hline 19 & $\mathrm{M}$ & 49 & $2 /$ aa & $<5$ & $<5$ & 45 & 50 & 450 \\
\hline 20 & $\mathrm{~F}$ & 38 & $0.5 / \mathrm{ac}$ & $<5$ & $<5$ & 23 & 20 & 297 \\
\hline 21 & $M$ & 50 & $0.5 / \mathrm{ac}$ & $<5$ & $<5$ & 8 & 10 & 302 \\
\hline 22 & $\mathrm{~F}$ & 42 & $1 / \mathrm{ac}$ & $<5$ & $<5$ & 25 & 24 & 434 \\
\hline 23 & $M$ & 49 & $1 / \mathrm{ac}$ & $<5$ & $<5$ & 23 & 21 & 510 \\
\hline 24 & $\mathrm{~F}$ & 21 & $0.5 / \mathrm{ac}$ & $<5$ & $<5$ & 50 & 38 & 500 \\
\hline
\end{tabular}

pa, Pituitary adenoma; aa, adrenal adenoma; ac, adrenal carcinoma. 
gradient centrifugation (19). After separation, PBMC preparations were washed three times and resuspended in complete medium (RPMI 1640 medium enriched with 10\% heat-inactivated fetal bovine serum, 1\% glutamine and $50 \mu \mathrm{g} / \mathrm{ml}$ gentamicin). An aliquot $\left(3 \times 10^{6}\right.$ cells $/ \mathrm{ml}$ complete medium) of PBMC preparations from five patients randomly taken from the two major groups of patients and from five healthy controls was incubated overnight in culture flasks $\left(37^{\circ} \mathrm{C}, 95 \%\right.$ air , $5 \% \mathrm{CO}_{2}$ ) to remove adherent cells/monocytes. Nonadherent PBMC were centrifuged and resuspended in complete medium at $5 \times 10^{6}$ cells $/ \mathrm{ml}$ complete medium and incubated with the specific monoclonal antibody anti-CD56 (Becton Dickinson, Lincoln Park, NJ, USA) for $20 \mathrm{~min}$ at $4{ }^{\circ} \mathrm{C}$, because anti-CD56 recognizes more than $95 \%$ of NK cells (2). After incubation, NK cells were counted by cell sorting.

PBMC preparations $\left(7.5 \times 10^{6} / \mathrm{ml}\right)$ were then exposed to complete medium containing modifiers or alone. Cortisol (Sigma, St Louis, MO, USA) was initially dissolved in 95\% ethanol and then diluted in distilled water to give a $1 \mathrm{mmol} / \mathrm{l}$ stock solution, which was stored at $4^{\circ} \mathrm{C}$. For use in experiments, the steroid was promptly diluted in complete medium to a final concentration of $10^{-6} \mathrm{~mol} / \mathrm{l}$. Ethanol at the final concentration added to effectors (ranging from 100 to $1 \mu \mathrm{g} / \mathrm{ml}$ ) did not alter the cell viability or NK activity of our preparations. $\operatorname{rIFN}-\gamma$ (Sigma) was diluted in complete medium and used at the concentration of $650 \mathrm{IU} / \mathrm{ml}$. Incubation at $37^{\circ} \mathrm{C}$ in a humidified atmosphere of $95 \%$ air and $5 \% \mathrm{CO}_{2}$ lasted $20 \mathrm{~h}$.

Preliminary experiments on the dose-response curve showed that these concentrations of modifiers (cortisol or $\operatorname{rIFN}-\gamma$ ) and this incubation time, give the optimal inhibition or enhancement respectively, of NK activity $(8,10,12)$.

After incubation, NK assay was performed using a non-radiometric technique reported in detail elsewhere (20). K562 cells from a human chronic myelogenous leukaemia cell line were used as targets. NK activity was expressed in lytic units (LU) $/ 10^{7}$ PBMC, according to the equation proposed by Pross et al. (21). When the effects of positive or negative modifiers were assessed, data were expressed as percentage changes from control values obtained under the same conditions in the absence of modifiers (spontaneous activity) (20).

\section{Hormone assays}

Serum and urinary free cortisol were determined with a specific RIA method purchased from Sorin Biomedica (Saluggia, Italy). ACTH was assayed by a specific IRMA method purchased from Nichols Institute (San Juan Capistrano, CA, USA). All hormone assays were performed in the same laboratory. Intra- and interassay coefficients of variation for the two above-mentioned variables were less than $8 \%$ and $12 \%$ respectively.

\section{Statistics}

All results are presented as means \pm S.E., except for the two ectopic ACTH syndromes. For all participants, data on the spontaneous NK activity were expressed as absolute values (LU/10 ${ }^{7} \mathrm{PBMC}$ ), whereas levels of cytotoxicity after incubation of effector cells with modifiers were expressed as percentage changes from spontaneous activity. Because of the skewed distribution, basal values of cytotoxicity or changes from spontaneous activity in controls and pituitarydependent or adrenal-dependent patients were compared using the Wilcoxon rank test or the MannWhitney test where appropriate. When correlations were sought between immune parameters and ACTH or cortisol concentrations, Spearman's rank correlation coefficient was calculated. Outliers were not eliminated from the data sets. In all circumstances, $P=0.05$ or less was regarded as significant.

\section{Results}

Plasma ACTH concentration was greater in pituitarydependent patients (Table 2). Serum and urinary free cortisol concentrations were significantly greater in adrenal-dependent patients than in pituitary-dependent ones.

In the two patients affected with ectopic ACTH secretion, ACTH plasma concentrations were much greater than in pituitary-dependent patients; both serum and urinary free cortisol concentrations were

Table 2 Hormonal patterns in patients with Cushing's syndrome. Values are means \pm S.E.M.

\begin{tabular}{|c|c|c|c|c|c|}
\hline & \multicolumn{2}{|c|}{ Plasma ACTH (pg/ml) } & \multicolumn{2}{|c|}{ Serum cortisol $(\mu \mathrm{g} / \mathrm{dl})$} & \multirow{2}{*}{$\begin{array}{l}\text { Urinary free cortisol } \\
\qquad(\mu \mathrm{g} / 24 \mathrm{~h})\end{array}$} \\
\hline & $0800 \mathrm{~h}$ & $2000 \mathrm{~h}$ & $0800 \mathrm{~h}$ & $2000 \mathrm{~h}$ & \\
\hline $\begin{array}{l}\text { Pituitary-dependent } \\
\quad(n=12) \\
\text { Adrenal-dependent }\end{array}$ & $44.5 \pm 8.3$ & $45.0 \pm 7.5$ & $16.7 \pm 0.7$ & $16.6 \pm 1.9$ & $246.3 \pm 46.4$ \\
\hline $\begin{array}{l}\quad(n=12) \\
\text { Ectopic ACTH }\end{array}$ & $<5$ & $<5$ & $31.0 \pm 4.1^{* *}$ & $27.6 \pm 3.2^{\star *}$ & $529.4 \pm 121.9^{* *}$ \\
\hline $\begin{array}{l}\text { Patient } 1 \\
\text { Patient } 2\end{array}$ & $\begin{array}{l}196 \\
640\end{array}$ & $\begin{array}{l}194 \\
520\end{array}$ & $\begin{array}{l}>80 \\
>80\end{array}$ & $\begin{array}{l}>80 \\
>80\end{array}$ & $\begin{array}{l}1500 \\
1090\end{array}$ \\
\hline
\end{tabular}

${ }^{\star *} P<0.01$ compared with pituitary-dependent group. 
Table 3 Mean \pm S.E. levels of cytotoxicity (absolute values, LU/ $10^{7}$ PBMC) obtained after in vitro incubation of $\mathrm{PBMC}$ in the presence or absence of modifiers, and mean numbers of $\mathrm{CD}^{+} 6^{+}$cells at $0800 \mathrm{~h}$ (percentage values)

\begin{tabular}{|c|c|c|c|}
\hline & $\begin{array}{l}\text { Controls } \\
(n=15)\end{array}$ & $\begin{array}{l}\text { Pituitary-dependent } \\
\qquad(n=12)\end{array}$ & $\begin{array}{c}\text { Adrenal-dependent } \\
\quad(n=12)\end{array}$ \\
\hline \multicolumn{4}{|l|}{$0800 \mathrm{~h}$} \\
\hline Spontaneous & $16.2 \pm 1.4 \dagger+\dagger$ & $10.9 \pm 2.1$ & $6.0 \pm 1.0$ \\
\hline+ rlFN- $\gamma(650 \mathrm{lU} / \mathrm{ml})$ & $29.5 \pm 2.4^{* * \star}+\dagger \dagger$ & $14.7 \pm 3.8^{* * *}$ & $11.2 \pm 1.9^{\star * *}$ \\
\hline+ cortisol $\left(10^{-6} \mathrm{~mol} / \mathrm{l}\right)$ & $8.7 \pm 1.0^{* * *}+\dagger \dagger$ & $7.3 \pm 1.5^{\star \star *}$ & $5.3 \pm 0.9^{\star \star \star}$ \\
\hline CD $56^{+}$cells $(n=5)$ & $15.3 \pm 1.5$ & $14.9 \pm 1.5$ & $14.6 \pm 1.4$ \\
\hline \multicolumn{4}{|l|}{$2000 \mathrm{~h}$} \\
\hline Spontaneous & $6.4 \pm 1.7$ & $11.6 \pm 2.5$ & $9.0 \pm 1.7$ \\
\hline+ rlFN- $\gamma(650 \mathrm{IU} / \mathrm{ml})$ & $9.7 \pm 1.3^{* \star *}$ & $17.7 \pm 3.7^{* * *}$ & $11.2 \pm 2.0^{* * *}$ \\
\hline$+\operatorname{cortisol}\left(10^{-6} \mathrm{~mol} / \mathrm{l}\right)$ & $2.0 \pm 0.4^{\star \star \star}$ & $7.7 \pm 1.7^{\star \star *}$ & $6.7 \pm 1.1^{\star *}$ \\
\hline
\end{tabular}

${ }^{* *} P<0.01,{ }^{* *} P<0.001$ compared with spontaneous; $† \dagger \dagger P<0.001$ compared with $2000 \mathrm{~h}$.

much greater and superimposable, respectively, with those registered for adrenal-dependent Cushing's patients.

Both in controls and in patients, the levels of spontaneous NK cell activity showed wide interindividual variability.

Mean spontaneous cytotoxicity at $0800 \mathrm{~h}$ was greater in controls; statistical significance was attained in the comparison between controls and both groups of patients $(P<0.05$ compared with the pituitary-dependent group; $P<0.01$ compared with the adrenaldependent group). However, no significant differences between controls and patients were observed for the percentage of $\mathrm{CD} 56^{+}$positive cells (NK cells) (Table 3 ). The two patients with ectopic ACTH secretion displayed lower levels of cytotoxicity than healthy subjects (Fig. 1; Tables 3, 4). In the second circadian stage $(2000 \mathrm{~h})$,

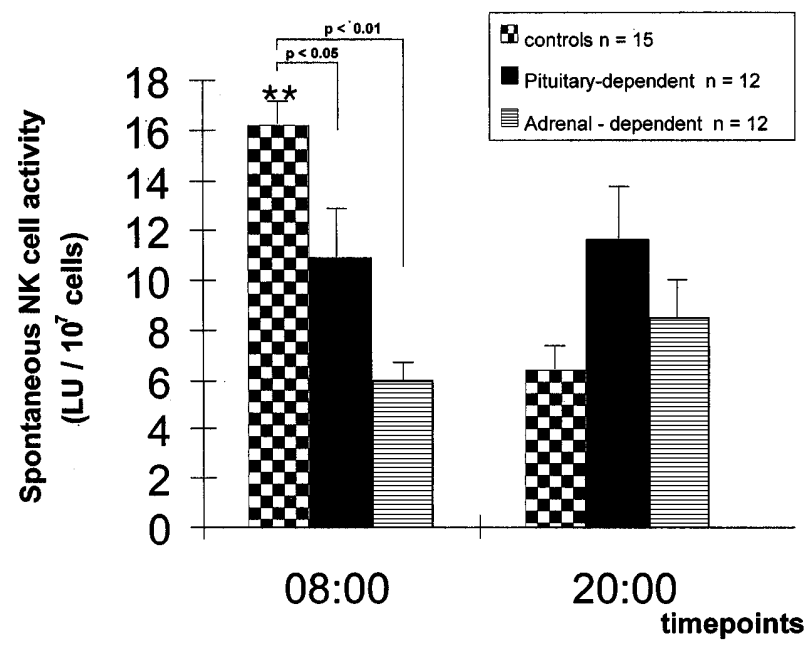

Figure 1 Spontaneous NK cell activity of PBMC preparations obtained at two opposing circadian stages (0800 and $2000 \mathrm{~h}$ ) from healthy subjects (controls) and patients with Cushing's syndrome, either pituitary-dependent or adrenal-dependent. Data are expressed as absolute values (mean \pm S.E.). ${ }^{\star \star} P<0.01$ compared with values obtained at $2000 \mathrm{~h}$ values were similar in controls and all patients (Fig. 1; Tables 3, 4).

In agreement with previous observations $(13,14)$, healthy subjects displayed significantly greater levels of spontaneous NK activity at $0800 \mathrm{~h}$ than at $2000 \mathrm{~h}$ $(P<0.01)$. No appreciable differences between the two time points were observed in Cushing's patients.

In the morning, the percentage rIFN- $\gamma$-induced boosting of NK activity was significantly greater in controls than in patients with pituitary-dependent $(P<0.001)$ or adrenal-dependent $(P<0.001)$ Cushing's syndrome; at $2000 \mathrm{~h}$, statistical significance was reached only between controls and the latter group of patients $(P<0.01)$ (Fig. 2; Table 3). The percentage rIFN- $\gamma$-dependent enhancement of cytotoxicity in ectopic ACTH secretion is shown in Table 4.

In healthy subjects, rIFN- $\gamma$-dependent enhancement of cytotoxicity was significantly greater at $0800 \mathrm{~h}$ than at $2000 \mathrm{~h}$, both as absolute $(P<0.001)$ and percentage

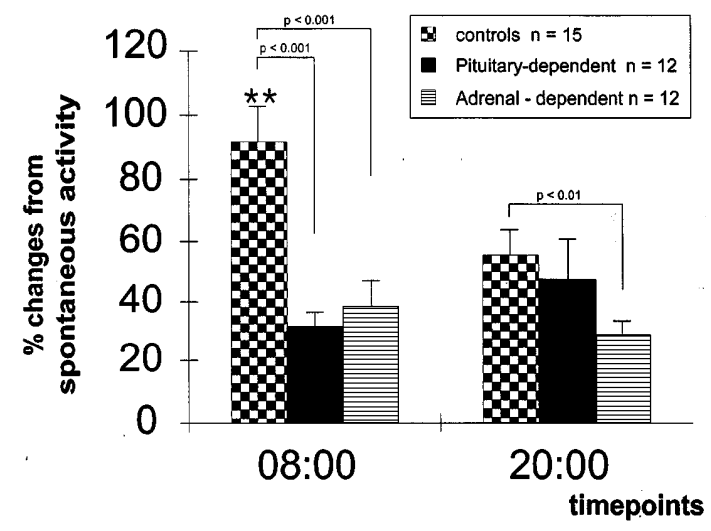

Figure 2 In vitro responsiveness to $\mathrm{rlFN}-\gamma(650 \mathrm{IU} / \mathrm{ml})$ of PBMC preparations obtained at two opposing circadian stages (0800 and $2000 \mathrm{~h}$ ) from healthy subjects (controls) and patients with Cushing's syndrome, either pituitary-dependent or adrenal-dependent. Data are expressed as percentage changes (mean \pm S.E.) from spontaneous activity of PBMC preparations taken as 100 . ${ }^{\star \star} P<0.01$ compared with values obtained at $2000 \mathrm{~h}$. 
Table 4 Levels of cytotoxicity (absolute values expressed as LU/10 7 PBMC, and percentage values) obtained after in vitro incubation of PBMC in the presence or absence of modifiers in two patients with ectopic ACTH secretion.

\begin{tabular}{|c|c|c|c|c|}
\hline & \multicolumn{2}{|c|}{ Patient 1} & \multicolumn{2}{|c|}{ Patient 2} \\
\hline & $\begin{array}{l}\text { Cytotoxicity } \\
\text { (LU/107 cells) }\end{array}$ & $\begin{array}{l}\text { Change from } \\
\text { spontaneous } \\
\text { activity (\%) }\end{array}$ & $\begin{array}{l}\text { Cytotoxicity } \\
\text { (LU/107 cells) }\end{array}$ & $\begin{array}{c}\text { Change from } \\
\text { spontaneous } \\
\text { activity (\%) }\end{array}$ \\
\hline \multicolumn{5}{|l|}{$0800 \mathrm{~h}$} \\
\hline Spontaneous & 5.1 & & 2.8 & \\
\hline$+\mathrm{rIFN}-\gamma(650 \mathrm{IU} / \mathrm{ml})$ & 8.6 & +68.6 & 4.6 & +64.2 \\
\hline+ cortisol $\left(10^{-6} \mathrm{~mol} / \mathrm{l}\right)$ & 4.8 & -5.8 & 2.3 & -17.8 \\
\hline \multicolumn{5}{|l|}{$2000 \mathrm{~h}$} \\
\hline Spontaneous & 6.0 & & 4.0 & \\
\hline$+\mathrm{rIFN}-\gamma(650 \mathrm{IU} / \mathrm{ml})$ & 9.1 & +51.6 & 7.3 & +82.5 \\
\hline+ cortisol $\left(10^{-6} \mathrm{~mol} / \mathrm{l}\right)$ & 4.9 & -18.3 & 3.4 & -15.0 \\
\hline
\end{tabular}

values $(P<0.01)$, whereas time-dependent differences were not appreciable in Cushing's patients (Fig. 2; Table 3).

The percentage cortisol-dependent inhibition was always less in patients than in healthy subjects. At $0800 \mathrm{~h}$, patients with adrenal-dependent glucocorticoid excess showed the lowest levels of inhibition, with significant differences from both controls $(P<0.01)$ and pituitary-dependent Cushing's patients $(P<0.01)$ (Fig. 3; Table 3). At $2000 \mathrm{~h}$, controls displayed the highest degree of percentage inhibition, whereas the lowest was again observed in patients with adrenaldependent Cushing's syndrome (Fig. 3). In the two patients affected by ectopic ACTH secretion, cortisoldependent inhibition was even lower than in patients with adrenal-dependent glucocorticoid excess (Table 4).

In all patients, levels of cortisol-mediated inhibition recorded at $0800 \mathrm{~h}$ and at $2000 \mathrm{~h}$ were not significantly different. In contrast, in controls, steroid-dependent

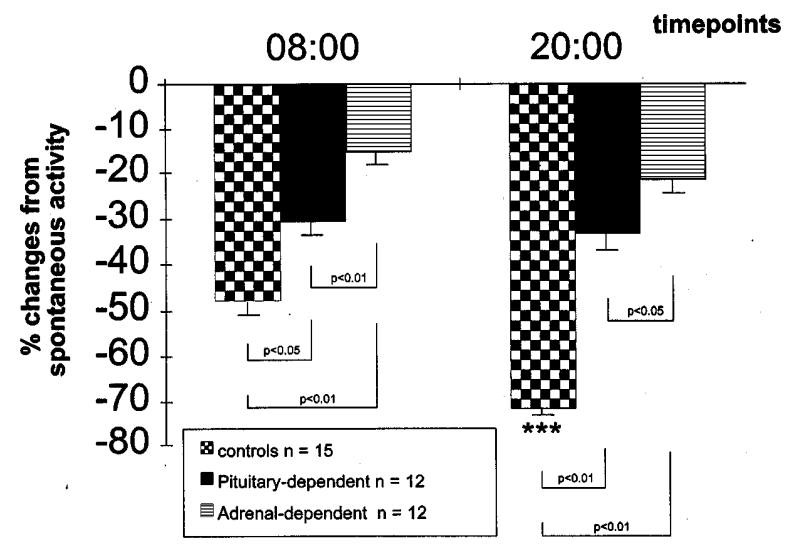

Figure 3 In vitro responsiveness to cortisol $\left(10^{-6} \mathrm{~mol} / \mathrm{l}\right)$ of PBMC preparations obtained at two opposing circadian stages (0800 and $2000 \mathrm{~h}$ ) from healthy subjects (controls) and patients with Cushing's syndrome, either pituitary-dependent or adrenal-dependent. Data are expressed as percentage changes (mean \pm S.E.) from spontaneous activity of PBMC preparations taken as 100 . ${ }^{* \star *} P<0.001$ compared with values obtained at $0800 \mathrm{~h}$. reduction of cytotoxicity was significantly greater at 2000 h (Fig. 3; Table 4; $P<0.001$ ).

To search for endocrine-immune relationships, the means between 0800 and $2000 \mathrm{~h}$ values were calculated for immune variables and plasma ACTH in pituitary- or adrenal-dependent patients. A significant positive correlation was apparent in pituitary-dependent Cushing's patients between mean levels of spontaneous NK activity and mean plasma ACTH $(r=0.64$, $P<0.02$; Fig. 4A). In addition, a significant inverse correlation was obtained between mean cortisoldependent inhibition of spontaneous activity (percentage values) and mean plasma ACTH $(r=-0.69, P<0.02$; Fig. 4B).

No correlation was observed between mean levels of spontaneous cytotoxicity and urinary free cortisol in the pituitary-dependent group of patients (Fig. 5A), whereas it was apparent in the adrenal-dependent group ( $r=-0.67, P<0.02$; Fig. $5 \mathrm{~B})$. It should be noted that the patient who appears as outlier in Fig. 5B was one of the patients affected with adrenal-dependent Cushing's syndrome having the greatest serum cortisol concentration and spontaneous cytotoxicity values far below the means observed in this group (0800 h: 0.9 $\mathrm{LU} / 10^{7}$ PBMC; $2000 \mathrm{~h}: 4 \mathrm{LU} / 10^{7}$ PBMC).

\section{Discussion}

Our data are the first to deal with NK cell activity in Cushing's syndrome as a function of different aetiologies and hence divergent patterns of ACTH and other POMCderived peptides in the face of glucocorticoid excess. Recent work by Kronfol et al. (22) indicating a reduced NK cell activity in Cushing's patients, did not take into account the aetiology of the glucocorticoid excess.

As a general feature, at $0800 \mathrm{~h}$ our Cushing's patients displayed significantly lower levels of spontaneous NK cell activity than did controls, in agreement with reported data (22). It is established that glucocorticoids interfere profoundly with the function of many immunocytes $(23,24)$. As one might expect, 

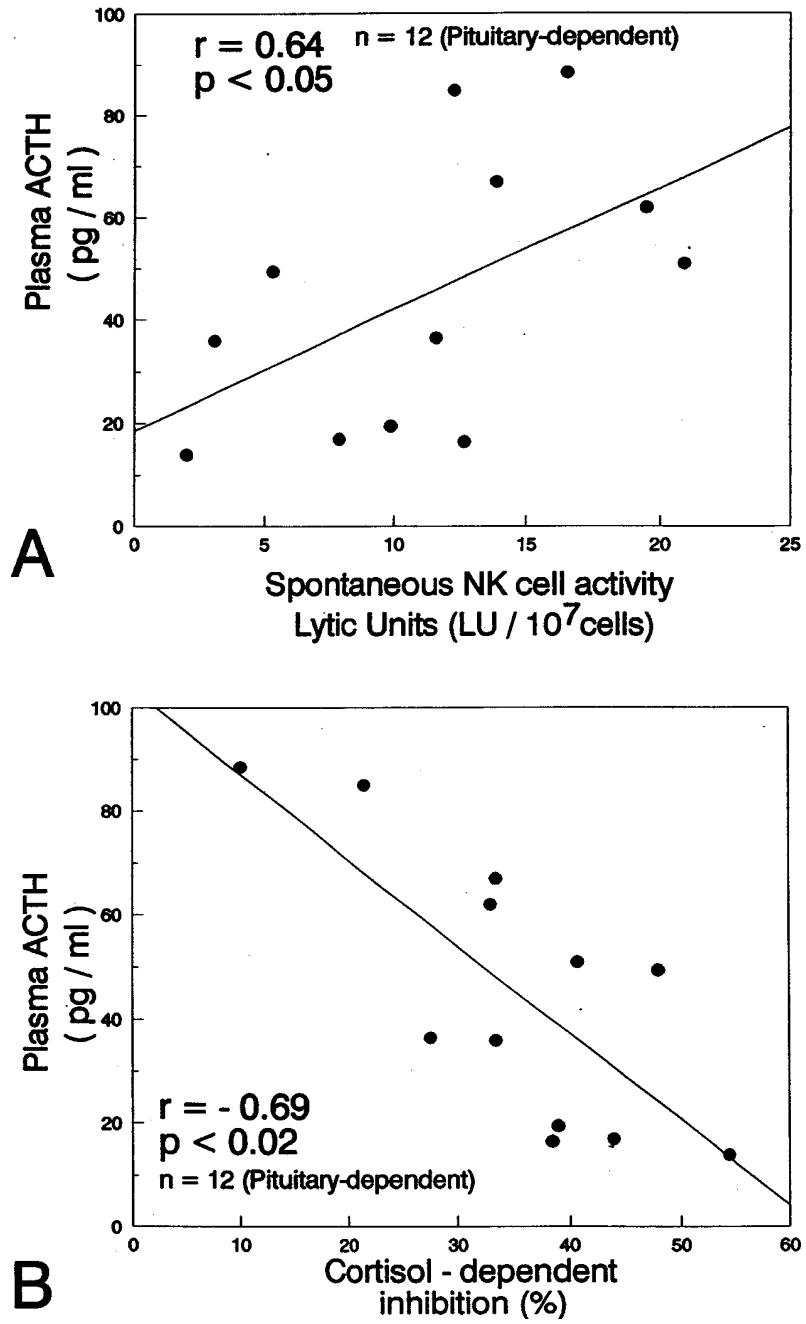

Figure 4 (A) Correlation between means of 0800 and $2000 \mathrm{~h}$ spontaneous NK cell activity and plasma ACTH in patients with pituitary-dependent Cushing's syndrome. Data are validated by Spearman's rank correlation test: $r=0.64 ; P<0.02$. (B) Correlation between means of 0800 and $2000 \mathrm{~h}$ cortisol-dependent inhibition of spontaneous NK cell activity and plasma ACTH in patients with pituitary-dependent Cushing's syndrome. Data are validated by Spearman's rank correlation test: $r=-0.69 ; P<0.02$.

chronic endogenous glucocorticoid excess also reduces natural cytotoxicity. It should be pointed out that, as found by other authors (22), a count of circulating NK effectors by surface phenotype analysis did not reveal any abnormality of the number of $\operatorname{CD} 56^{+}$cells. It is arguable that, in vivo, cortisol excess affects the biochemical machinery responsible for cytotoxicity (10), while sparing cell integrity and viability. Extensive studies have demonstrated that both the spontaneous activity and the cortisol-dependent effects on NK cytotoxicity are mediated, to a remarkable extent, by $\mathrm{Ca}^{2+}$-dependent pathways (10). Abnormalities of intratracellular calcium traffic might be responsible for glucocorticoid-mediated immune alterations.
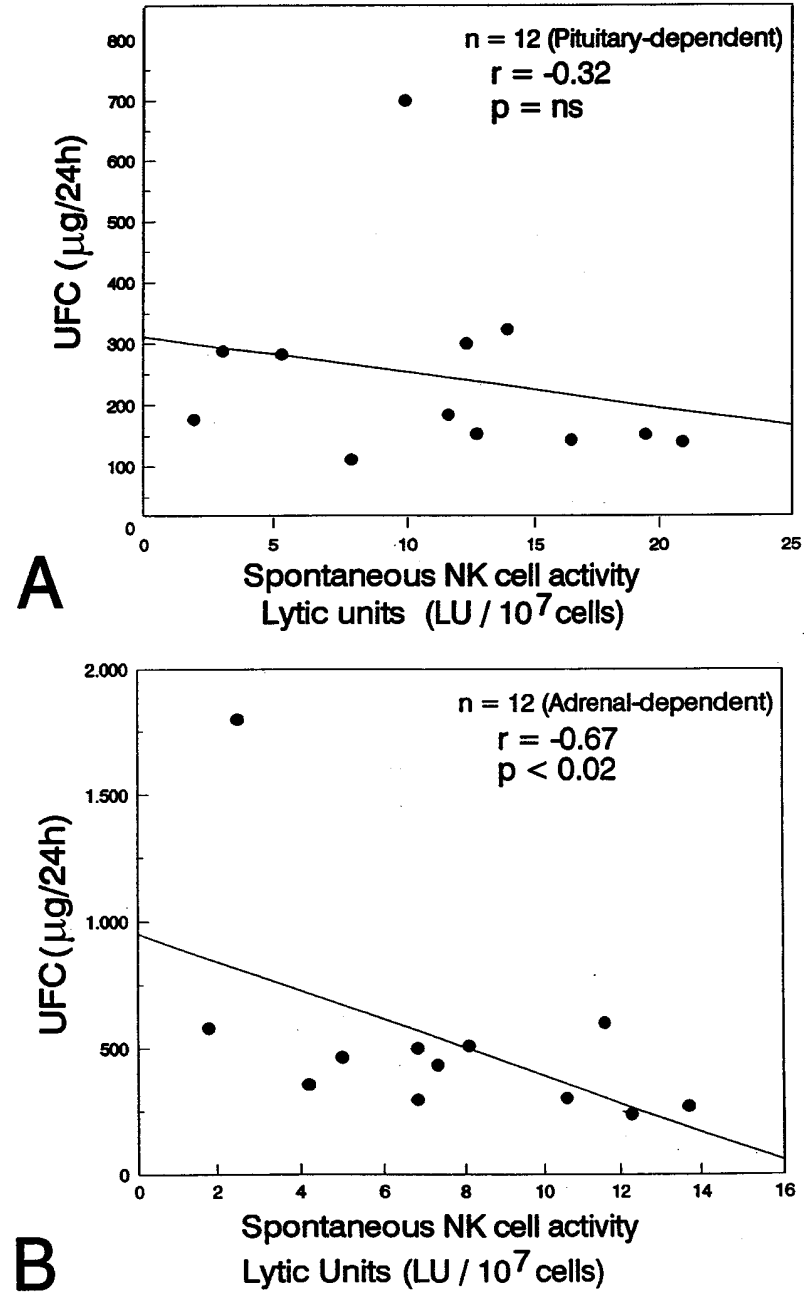

Figure 5 (A) Correlation between means of 0800 and $2000 \mathrm{~h}$ spontaneous NK cell activity and urinary free cortisol in patients with pituitary-dependent Cushing's syndrome. Data are validated by Spearman's rank correlation test: $r=-0.32$; ns, not significant. (B) Correlation between means of 0800 and $2000 \mathrm{~h}$ spontaneous NK cell activity and urinary free cortisol in patients with adrenaldependent Cushing's syndrome. Data are validated by Spearman's rank correlation test: $r=-0.67 ; P<0.02$.

Levels of spontaneous activity were greater in pituitarydependent Cushing's patients than in adrenal-dependent ones. This result is conceivably due, not only to lower serum cortisol in the first group of patients with respect to the latter, but also to greater plasma ACTH concentrations. POMC-derived peptides have been shown to modulate in vitro NK cell activity positively and, notably, to potentiate the effects of stimulatory cytokines $(11,12)$. In this regard, our data can be viewed as compatible with a positive immunomodulatory role for ACTH in vivo also, consistent with previous observations in patients with anorexia nervosa, in whom the magnitude of ACTH release after corticotrophinreleasing hormone challenge was correlated with incremental NK cytotoxicity after IL-2 (25). 
The observation, in the present study, of a negative correlation between percentage cortisol-dependent inhibition and plasma ACTH in pituitary-dependent cases could be an additional piece of evidence for the ability of the pituitary peptide to effectively counterbalance in vivo glucocorticoid-induced immunosuppression, as it has also been documented in vitro (12). In adrenaldependent patients, we observed a negative correlation between levels of spontaneous NK cell activity and urinary free cortisol. Although statistical significance could be affected by the presence of an outlier patient, our data are consistent with the view that the immunosuppressive properties of unopposed glucocorticoids exert greater influence $(6,12)$.

No definitive conclusions can be drawn from our two patients with ectopic ACTH production. In such patients, concentrations of circulating glucocorticoids are conceivably too great to be counterbalanced by POMC-derived peptides of neoplastic origin.

As for the spontaneous NK cell activity, $r I F N-\gamma$ dependent enhancement was lower in patients with Cushing's syndrome than in controls. Interrelationships between glucocorticoids and cytokines have been a focus of extensive research (26). In addition to decreasing production of cytokines, glucocorticoids interfere with their action by inhibiting cytokine-dependent phosphorylation of several intracellular proteins or affecting synthesis of soluble or cellular specific receptors (27-29). We can not exclude that, in our patients, hypercortisolism resulted in analogous inhibition of the IFN- $\gamma$ system. It remains to be elucidated whether IFN- $\gamma$ release, IFN- $\gamma$ receptor integrity, or both, are impaired.

As far as in vitro responsiveness to cortisol is concerned, PBMC obtained from Cushing's patients were less sensitive to the steroid than were those from control subjects. A lower degree of in vitro effectiveness of the hormone in Cushing's patients could be due to reduced availability of specific receptors on mononuclear cells as a consequence of endogenous hypercortisolism. In this view, recent literature reports the decrease in corticosteroid sensitivity of peripheral immunocytes exposed to excess endogenous or exogenous glucocorticoids $(29,30)$. In such acute conditions serum cortisol levels are often comparable to those observed in Cushing's patients. Further studies are needed to determine the molecular mechanisms of glucocorticoid resistance in these circumstances.

Notwithstanding limitations due to our consideration of only two time points over the course of the 24-h day, our results also suggest that, in Cushing's patients, diurnal variations of spontaneous NK cell activity and in vitro responsiveness to physiological modifiers are lost. It is held that the HPA system is strongly organized according to a circadian programme and can be considered to be one important endogenous synchronizer of many bodily functions, including immune reactions among others $(16,31,32)$. It is not surprising, therefore, that, in the presence of profound abnormalities of the circadian pattern of HPA hormones, diurnal immunological variations are no longer apparent.

To conclude, our data demonstrate that, in patients with Cushing's syndrome, NK cell activity is impaired. The degree of NK cell impairment is apparently greater in patients with autonomous adrenal hypersecretion, in whom glucocorticoid effects are unopposed by ACTH. Overall, our results provide an additional piece of evidence for the role of HPA hormones in the modulation of natural cytotoxicity in vivo.

\section{Acknowledgements}

This work was supported by grants from Ministero dell'Università e della Ricerca Scientifica e Tecnologica.

\section{References}

1 Trinchieri G. Biology of natural killer cells. Advances in Immunology 198947 181-376.

2 Ritz J, Campen TJ, Schmidt RE, Royer HD, Hercend T, Hussey RE \& Reinherz EL. Analysis of T cell receptor gene rearrangement and expression in human natural killer (NK) clones. Science 1985228 1540-1546.

3 Ljunggren HG \& Karre K. In search of the 'missing self': MHC molecules and NK cell recognition. Immunology Today 199011 237-244.

4 Wolf SF, Sieburth D \& Sypek J. Interleukin 12: a key modulator of immune function. Stem Cell 199412 154-168.

5 Biron CA \& Gazzinelli RT. Effects of IL-12 on immune responses to microbial infections: a key mediator in regulating disease outcome. Current Opinion in Immunology 19957 485-496.

6 Parrillo JE \& Fauci AS. Comparison of the effector cells in human spontaneous cellular cytotoxicity and antibody-dependent cytotoxicity: differential sensitivity of effector cells to in vivo and in vitro corticosteroids. Scandinavian Journal of Immunology $1978 \mathbf{8}$ 99-107.

7 Holbrook NJ, Cox WI \& Horner HC. Direct suppression of natural killer activity in human peripheral blood leukocyte cultures by glucocorticoids and its modulation by interferon. Cancer Research 198343 4019-4025.

8 Gatti G, Cavallo R, Sartori ML, Del Ponte D, Masera RG, Salvadori A, Carignola R \& Angeli A. Inhibition by cortisol of human natural killer (NK) cell activity. Journal of Steroid Biochemistry 198726 49-58.

9 Angeli A, Masera RG, Staurenghi AH, Solomon S, Bateman A, Sartori ML, Lazzero A \& Griot G. The expanding field of hypothalamic-pituitary-adrenal modulation of human natural killer cell activity. Annals of the New York Academy of Sciences 1994 $719328-342$.

10 Masera RG, Gatti G, Sartori ML, Carignola R, Salvadori A, Magro $\mathrm{E} \&$ Angeli $\mathrm{A}$. Involvement of $\mathrm{Ca}^{2+}$-dependent pathways in the inhibition of human natural killer (NK) cell activity by cortisol. Immunopharmacology 198918 11-22.

11 McGlone JJ, Lumpkin EA \& Norman RL. Adrenocorticotropin stimulates natural killer cell activity. Endocrinology 1991129 1653-1658.

12 Gatti G, Masera RG, Pallavicini L, Sartori ML, Staurenghi A \& Angeli A. Interplay in vitro between ACTH, $\beta$-endorphin, and glucocorticoids in the modulation of spontaneous and lymphokine-inducible human natural killer (NK) cell activity. Brain Behavior and Immunity 19937 16-28.

13 Gatti G, Cavallo R, Del Ponte D, Sartori ML, Masera RG, Carignola R, Carandente F \& Angeli A. Circadian changes of human natural 
killer (NK) cells and their in vitro susceptibility to cortiso inhibition. Annual Review of Chronopharmacology 19863 75-78.

14 Gatti G, Cavallo R, Sartori ML, Carignola R, Del Ponte D, Masera RG, Salvadori A \& Angeli A. Circadian variations of interferoninduced enhancement of natural killer (NK) cell activity. Cancer Detection and Prevention 198812 431-438.

15 Mozzaniga N, Finzi AF, Foppa S, Vignati G \& Villa ML. Association between circadian rhythm of endogenous hypothalamic opioid peptides and of natural killer cell activity. International Journal of Immunopharmacology 199113 317-321.

16 Angeli A, Gatti G, Sartori ML \& Masera RG. Chronobiological aspects of neuroendocrine-immune network. Regulation of human natural killer (NK) cell activity as a model. Chronobiologia 199219 93-110.

17 Sauer J, Stalla GK, Muller OA \& Arzt E. Inhibition of interleukin-2mediated lymphocyte activation in patients with Cushing's syndrome: a comparison with hypocortisolemic patients. Neuroendocrinology 199459 144-151.

18 Aucott JN. Glucocorticoids and infections. Endocrinology and Metabolism Clinics of North America 199423 655-670.

19 Boyum A. Isolation of mononuclear cells and granulocytes from human blood. Scandinavian Journal of Clinical and Laboratory Investigation $19682131-50$.

20 Masera RG, Bateman A, Muscettola M, Solomon S \& Angeli A. Corticostatins/defensins inhibit in vitro NK activity and cytokine production by human peripheral blood mononuclear cells. Regulatory Peptides 199662 13-21.

21 Pross HF, Baines MG, Rubin P, Schragge P \& Patterson MS Spontaneous human lymphocyte-mediated cytotoxicity against tumor target cells. IX. The quantization of human natural killer cell activity. Journal of Clinical Immunology 1981 1 52-63.

22 Kronfol Z, Starkman M, Schteingart DE, Singh V, Zhang O \& Hill E. Immune regulation in Cushing's syndrome: relationship to hypothalamic-pituitary-adrenal axis hormones. Psychoneuroendocrinology 199721 599-608.

23 Goldstein RA, Dowen DL \& Fauci AS. Adrenal corticosteroids. In Inflammation: Basic Principles and Clinical Correlates, pp 1061-1081. Eds JL Gallin, IM Goldstein \& R Snyderman. New York: Raven Press, 1992.
24 Schleimer RP, Claman HN \& Oronsky A. Anti-inflammatory Steroid Action. Basic and Clinical Aspects, pp 564. New York: Academic Press, 1989.

25 Staurenghi A, Masera RG, Prolo P, Griot G, Sartori ML, Ravizza L \& Angeli A. Hypothalamic-pituitary-adrenal axis function, psychopathological traits and natural killer (NK) cell activity in anorexia nervosa. Psychoneuroendocrinology 199722 575590.

26 Boumpas DT, Chrousos GP, Wilder RL, Cupps TR \& Balow JE. Glucocorticoid therapy for immune-mediated diseases: basic and clinical correlates. Annals of Internal Medicine 1993119 1198-1208.

27 Paliogianni F, Ahuja SS, Balow JP, Balow JE \& Boumpas DT. Novel mechanism for inhibition of T cells by glucocorticoids (GC): GC modulate signal transduction through IL-2 receptor. Journal of Immunology 1993151 4081-4089.

28 Wu CY, Fargeas C, Nakajima T \& Delespesse G. Glucocorticoids suppress the production of interleukin 4 by human lymphocytes. European Journal of Immunology 199121 2645-2647.

29 Sauer J, Polack E, Wikinski S, Holsboer F, Stalla GK \& Arzt E. The glucocorticoid sensitivity of lymphocytes changes according to the activity of the hypothalamic-pituitary-adrenocortical system. Psychoneuroendocrinology 199520 269-280.

30 De Rijk RH, Petrides J, Deuster P, Gold PW \& Sternberg EM. Changes in corticosteroid sensitivity of peripheral blood lymphocytes after strenuous exercise in humans. Journal of Clinical Endocrinology and Metabolism 199681 228-235.

31 Angeli A. Glucocorticoid secretion: a circadian synchronizer of the human temporal structure. Journal of Steroid Biochemistry $198319545-554$.

32 Angeli A, Gatti G \& Masera RG. Chronobiology of hypothalamicpituitary-adrenal and renin-angiotensin-aldosterone systems. In Biological Rhythms in Clinical and Laboratory Medicine, pp 292314. Eds Y Touitou \& E Haus. Berlin, Heidelberg: Springer-Verlag, 1992.

Received 9 February 1998

Accepted 21 December 1998 